\title{
The Background Significance and Results Combing of the Research on the Quality Evaluation System of the Party Building Work in Colleges and Universities in the New Era
}

\author{
Chao Su \\ School of Marxism, Shanghai Jiao Tong University, Shanghai 200240, China \\ Email: suchao522426@sina.com
}

\begin{abstract}
The party building work of colleges and universities occupies a key position in all the work of colleges and universities. It is an important guarantee for promoting colleges and universities to fulfill the mission of cultivating people and achieve long-term and steady development. Entering the new era, under the new environment and situation, the party building work in colleges and universities is facing a series of opportunities and challenges. The current international political situation is becoming more and more severe. The domestic comprehensive and strict governance of the party continues to advance, and improving the quality of party building is an inevitable requirement of the new era and an important task of the new era. The work of party building in colleges and universities, like other grassroots party organizations, must have a scientific and reasonable quantitative evaluation system, otherwise its quality and level cannot be judged objectively. Based on the background and significance of the research on the quality evaluation system of party building work in universities, this article combs the research results of domestic scholars on the system, hoping to provide some reference for perfecting the system, improving the quality of party building work in universities and realizing the path and method of the overall development of universities.
\end{abstract}

Keywords: party building in colleges and universities, work quality, evaluation system, research results

\section{The realistic background of the research on the quality evaluation system of party building work in colleges and universities in the new era}

\subsection{Time background}

Nowadays, socialism with Chinese characteristics has entered a new era. Party building in colleges and universities is facing a series of unprecedented opportunities and challenges under the new historical node and the background of the times.

First of all, network information technology represented by Internet big data is developing rapidly. The openness of its content facilitates party building workers in colleges and universities to integrate resources and broaden their work areas; its diversity of methods enriches the content of party building work; its convenience of information extraction improves the effectiveness and efficiency of party building work. Therefore, big data has created unlimited opportunities in improving the working methods of party building, improving the quality of party building work, and innovating the system and mechanism of party building work in colleges and universities.

Secondly, with the profound changes in the world and national conditions, various social thoughts are surging, and Western ideological penetration has become more rampant. The Internet, as a carrier of information dissemination, has accelerated the promotion and transmission of anti-China, anti-socialism and other bad information. Various ideological and cultural exchanges are at the forefront of the fusion and confrontation, which has brought a huge impact on the party spirit, life, values, and world outlook of college party members and cadres, faculty, and student groups. Therefore, this urgently requires colleges and universities to improve the quality and level of party building work. Only in this way can the party and the state assume the great responsibility and sacred mission of the party and the state to establish morality and cultivate talents in colleges and universities in the new era and run a socialist university with Chinese characteristics.

Finally, since 2012, the major strategic deployments of "full-scale and strict governance of the party" ${ }^{\text {[1] }}$ have continued to advance and strengthened, and the general requirements for party building in the new era have also emphasized the need to "continuously improve the quality of party building" ${ }^{[2]}$. The relationship between party building work in colleges and the great project of party building is the relationship between the whole and the part. It is in an important position in the strategic layout of "comprehensively and strictly governing the party". The party building work runs through all the affairs 
of the school. Problems will arise if teaching and scientific research work in colleges and universities are not done well, but problems will arise if party building work in colleges and universities is not done well. Strengthening and improving party building in colleges and universities, and improving the quality and level of party building in colleges and universities are not only related to the party's leadership of colleges and universities, the direction of running schools in socialism, and the successors of the cause of socialism with Chinese characteristics, but also the effect of comprehensive and strict governance of the party in the new era and the in-depth advancement of the great project of party building.

\subsection{Practice background}

The central government pays great attention to the work of party building in colleges and universities. Since 2017, it has successively issued a number of targeted documents, covering ideological and political work in colleges and universities, student party building work, construction of party branches for college teachers, and regulations on the work of grassroots party organizations, etc. For example, in February 2017, the Central Committee of the Communist Party of China and the State Council issued the "Opinions on Strengthening and Improving Ideological and Political Work in Colleges and Universities under the New Situation". The document proposed that "adhere to the party's leadership over colleges and universities" as the basic principle for strengthening and improving the ideological and political work in colleges and universities. For example, in July 2018, the Organization Department of the Central Committee and the Ministry of Education jointly issued the "Key Tasks for Party Building in Colleges and Universities". The document emphasized the need to give full play to the leadership role of the party committees of colleges and universities, and strengthen the party building work of colleges and departments. The members and the party branch of teachers and students implement scientific and rigorous supervision, management and assessment. For example, in 2019, the General Office of the Ministry of Education issued the "Notice on Carrying out the Second Batch of New Era University Party Building Demonstration Creation and Quality Innovation Work", and through the development of "double innovation work", we selected comprehensively advanced and comprehensive college grassroots parties. Organization, which also demonstrates the strong emphasis on the quality of party building work in colleges and universities. For another example, recently, on April 16, 2021, the Central Committee of the Communist Party of China issued the revised "Regulations on the Work of Basic-level Organizations in Ordinary Colleges and Universities of the Communist Party of China." The party's overall leadership over colleges and universities. Compared with the previous, the newly revised "Regulations" directly understand the important position of party building in colleges and universities.

The publication of a series of documents from central ministries and functional departments clearly shows that the party and the government attach great importance to the quality of party building work in colleges and universities. It's a baton, and it's a touchstone. So, what kind of assessment system is feasible? What are the evaluation criteria and principles? Which evaluation methods of different subjects should be the same, and those should be different? Are there any shortcomings in current assessment methods? and many more. There are so many problems at the evaluation level of this kind that we urgently need to dig and study them in depth. Therefore, the work of party building in colleges and universities is very important. Therefore, the improvement of the quality of party building requires a scientific and reasonable evaluation system.

\section{Research on related discourses on the quality of party building in the new era}

Since 2012, the party and the state have been paying attention to the work of party building in colleges and universities, and have put forward a number of important expositions and profound concepts on party building in colleges and universities in the new era, covering aspects such as the construction of organizational positions, work patterns, and institutional mechanisms in colleges and universities. This is also an important module for improving the quality of party building.

\subsection{Focus on improving organizational power, and promote the construction of party organizations in colleges and universities}

The importance of the organizational strength of the grassroots party organization is mainly reflected in its role and significance. President Xi Jinping emphasized, "Only when the grassroots party organization is strong and the party members play their due role, can the foundation of the party be firm and the party can have combat effectiveness" ${ }^{\prime[3]}$. Therefore, the improvement of organizational power can further consolidate and strengthen the foundation of our party's governance. "The party's grass-roots organizations are the basis for ensuring the implementation of the party's line, policies, and decisionmaking arrangements. It is necessary to focus on improving organizational strength, highlight political functions, and integrate enterprises, rural areas, government agencies, schools, scientific research institutes, neighborhood communities, and social organizations. The construction of grass-roots party organizations has become a strong fighting fortress for propagating the party's propositions, implementing the party's decisions, leading grassroots governance, uniting and mobilizing the masses, and promoting reform and development" ${ }^{\prime[4}$. In addition, in July 2018, the President's speech at the National Organization 
Work Conference emphasized that "We must strengthen party building work in various fields such as enterprises, rural areas, government agencies, institutions, and communities, and promote the overall progress of grassroots party organizations and comprehensive excellence" ${ }^{[5]}$. The above discussion puts forward new requirements for improving the party building of colleges and universities. "Strong battle fortress", "all-round progress", and "all-round excellent" are all the most straightforward expressions of improving the quality of college party building. Take the improvement of organizational strength as the starting point, improve the quality of party building work, then strengthen the educational function of colleges and universities, and promote the in-depth development of party organization building in colleges and universities.

\subsection{Adhere to the leadership of the party and master the leading power of ideological and political work in colleges and universities}

In December 2016, President Xi Jinping emphasized at the National Conference on Ideological and Political Work in Colleges and Universities, "To successfully run higher education in our country, we must uphold the leadership of the party, firmly grasp the party's leadership over the work of colleges and universities, and make colleges and universities a strong position to uphold the leadership of the party. The party committee must ensure that colleges and universities are running in the correct direction, master the leadership of ideological and political work in colleges and universities, and ensure that colleges and universities always become strong positions for cultivating socialist cause builders and successors. Party committees at all levels must place ideological and political work in colleges and universities in an important position and strengthen leadership and guidance to form a work pattern with unified leadership by the party committee and comanagement of all departments and all aspects" ${ }^{[6]}$. The greatest advantage of the party's overall leadership lies in its ability to concentrate its efforts on major tasks. Historical experience tells us that the sustainable and healthy development of higher education depends on whether the party's leadership role in colleges and universities can play well. Since 2012, the Party Central Committee has been fighting corruption with an iron fist and has continued to promote a comprehensive and strict governance of the party's major strategic deployment, which has made the political life in the party in colleges and universities refreshed and the political ecology gradually cleared. This has provided a strong political guarantee for improving the quality of party building work in colleges and universities. As an important position for the country to train talents, colleges and universities undertake the important task of guiding the broad masses of young people to establish correct ideological awareness. Therefore, the party committee must firmly grasp the leadership of ideological and political work in colleges and universities in order to do a good job in educating people and provide a strong team of talents for improving the quality of college party building work.

\subsection{Adhere to the principal responsibility system under the leadership of the party committee, and improve the party building system and mechanism in colleges and universities}

President Xi Jinping emphasized at the 23rd National Party Building Work Conference of Higher Education Institutions that it is necessary to "adhere to and improve the principal responsibility system under the leadership of the party committee, continuously reform and improve the institutions and mechanisms of colleges and universities, and comprehensively promote the work of party building"[7]. The principal responsibility system under the leadership of the party committee distinguishes the division of functions between the party committee and the principal. The school's party committee is at the core of leadership, leading and supervising the school's various affairs. The principal and other administrative personnel must unconditionally and consciously accept the unified leadership of the party committee and resolutely and effectively implement the party committee's decisions and deployments. The inter-connected and differentiated relationship between the leadership of the party committee and the principal's responsibility has greatly enhanced the coordination and collaboration of the party and government leaders in colleges and universities, and the strength of the school affairs. At the same time, while playing a political leadership role, the school party committee must also support the principal to carry out various administrative tasks independently and responsibly. This system model further improves the internal governance structure, governance system and operating mechanism of colleges and universities, and provides a strong system guarantee for the improvement of the quality of party building work in colleges and universities.

President Xi's important expositions on party building work in colleges and universities have pointed out the direction of thinking and provided theoretical basis for doing a good job in party building in colleges and universities in the new era and improving the quality and level of party building in colleges and universities. 


\section{A summary of the research results of the current domestic scholars on the quality evaluation system of the party building work in colleges and universities}

\subsection{Research on the significance of quality evaluation of party building work in colleges and universities}

Primary-level party organizations in colleges and universities are responsible for the important responsibility of implementing the party's line, policy, ideas, and decision-making deployments to primary-level party organizations in colleges and universities. They are the organizational mobilizers that unite and lead the entire school's leading cadres and faculty and students to promote the reform and development of school construction and promote campus Safe, orderly, harmonious and stable battle fortresses and core pillars play a pivotal and active role in party building and reform and development in colleges and universities. Therefore, the assessment and evaluation of the work of the basic-level party organization in colleges and universities has obviously become an important field and key link of the overall work of the basic-level party building in colleges and universities. At present, the research on the significance of domestic experts and scholars on the evaluation and evaluation of party building quality in colleges and universities is divided into two dimensions: macroscopic and microscopic. The macro level focuses on the construction of the party organization, and the micro level focuses on the party branch of the organization, the faculty and the student party branch Dimensions. Li Yuanyuan and Zhang Qin ${ }^{[8]}$ believe that the establishment and improvement of the basic-level party organization assessment and evaluation system has diversified practical significance, which can not only improve the scientific level of party building work in colleges and universities, but also optimize the self-construction of basic-level party organizations in colleges and universities. At the same time, it can also implement the responsibility of governing the party and promote the orderly construction of grassroots party organizations. Du Hua ${ }^{[9]}$ believes that the construction and improvement of the evaluation system of grassroots party organizations is in line with the actual needs of strengthening party building in the new era, and this complex and important work must be done well. The above is mainly about the meaning of the macro level. Some scholars focus on the construction of party branches at all levels in colleges and universities. Si Lina, Song Yiwen, and Zhan Yanyan ${ }^{[10]}$ believe that improving the evaluation system of grassroots party organizations is conducive to the improvement of the overall quality of student party members and the standardized construction and high-level development of student party branches. Wang Deping ${ }^{[1]}$ believes that perfecting the evaluation and construction system of grassroots party organizations can ensure that all faculty and staff members maintain a high degree of consistency with the Party Central Committee in ideology and practice, and can promote the standardization of faculty and staff party branches.

\subsection{Research on the status quo of quality evaluation of party building work in colleges and universities}

At present, domestic scholars focus on the status quo of the evaluation index system of party building quality in colleges and universities, mainly in the two perspectives of the problems they face and the subject and object of evaluation. Cao Qingkui and Tai Xiuzhen ${ }^{[12]}$ pointed out that the evaluation standards of some colleges and universities are unscientific and unreasonable. They are mainly manifested in the single content, fewer quantitative indicators, low comparability and operability of some standards, and different colleges. The scores of the indicators are very different, all of which cause the quantitative assessment methods to fail to play their due role. Luo Hongyan ${ }^{[13]}$ emphasized that in some colleges and universities, the content of party building assessment is complicated, the assessment indicators are numerous, and they lack scientific and quantitative assessment standards, so that it is difficult to achieve the purpose of promoting work improvement through assessment. The above is to analyze the status quo from the perspective of the problems faced by the assessment, while other scholars conduct the research on the status quo from the level of the subject and object of the assessment. Li Fangzheng ${ }^{[14]}$ believes that in the evaluation system, evaluation objects, work objectives, and work evaluation have different characteristics. The former is multidimensional and variable, the middle is pluralistic and abstract, and the latter is indirect and latent. Specifically, college party organizations can be divided into three different levels: general party branches, party branches, and party groups. They can also be divided into organ party organizations, faculty party organizations, and student party organizations (multidimensional). The number of party members in a party branch is not static, and is always in constant increase or decrease (variability). The work objectives of colleges and universities include all aspects of organization and service, and each aspect of work also involves different evaluation standards (diversity). In fact, many goals of party building work are non-concretized. For example, the party organization cares about the interests and demands of teachers and students (abstraction). The work of party organization in colleges and universities generally plays a role indirectly through the enthusiasm of the majority of party members, so as to achieve the ultimate goal (indirectness). The 
effectiveness of party building work is a long-term process and not achieved overnight, which brings certain inconvenience (potential) to the evaluation work in the cycle.

\subsection{Research on the principles of constructing an quality evaluation index system of party building work in colleges and universities}

The appraisal index system for grassroots party building work in colleges and universities is a work guide for the practice of grassroots party building in colleges and universities. It is also an effective means and an important way to promote the scientific, standardized and institutionalized party building work in colleges and universities. The current academic research on its construction principles mainly focuses on comprehensiveness, focus, scientificity, objectivity, timeliness, feasibility, quantitative and qualitative aspects. Niu Heng, Gao Lina, and Liu Shuang ${ }^{[15]}$ believe that the construction of an evaluation index system for party building quality in colleges and universities should follow "scientific objectivity", "oriented operability", "comprehensive indicators", "quantitative details", "and "Advancing with the times" these five important principles. Scientific objectivity means that when formulating an evaluation plan and constructing an evaluation system, it is necessary to comply with the requirements of relevant policy documents, as well as the objective reality of the party building work of various colleges and universities, and to formulate goals in a scientific and reasonable manner. Oriented operability refers to the content of evaluation indicators, which must have an important guiding role in the grassroots party building work of colleges and universities and the thoughts and behaviors of teachers and students in the school. On the basis of this orientation, through evaluation practice, the indicators in the evaluation system must be evaluated. The content under the structure is specific, thereby improving the operability of the assessment system. The comprehensiveness of the indicators means that the evaluation system must have the characteristics of both the two-point theory and the key theory. That is, the evaluation points must not only fully reflect the overall requirements of the grass-roots party building work in colleges and universities, but also focus on and have inclination. The quantification of the detailed rules refers to clarifying the scope of responsibility and quantifying the detailed evaluation rules, that is, the work content corresponding to each index is specified and clarified, and the key points are given clear weights and measurement standards. Keeping pace with the times refers to keeping up with the pace of the times, constantly adjusting to cope with the endless new situations in the grassroots party building in colleges and universities, and proceeding from reality and continuous innovation. Fan Shan, She Tonghui, and Tu Fang ${ }^{[16]}$ believe that the evaluation standards for party building work are generally abstract. Therefore, when establishing evaluation standards, we should try our best to adopt feasible and operable quantitative methods to avoid non-concretized indicators. In addition, when encountering specific indicators that cannot be quantified, several qualitative methods can be adopted to carry out assessment and verification work.

\subsection{Research on ways to improve the quality evaluation index system of party building work in colleges and universities}

At present, academia has made certain research results on how to improve the quality evaluation index system of party building in colleges and universities. In general, scholars mostly focus on the methods of evaluation index evaluation, the direction and standard of index setting., The content of specific assessment indicators of party organizations at all levels in colleges and universities has not been systematically classified. Li Youqing ${ }^{[17]}$ believes that the index evaluation link in the index system should abandon the previous single rigid qualitative evaluation system, and combine the two methods of quantitative evaluation and qualitative analysis flexibly and comprehensively. The priority of the two methods must be distinguished: quantitative evaluation Mainly, supplemented by qualitative assessment. Tang Chaoji ${ }^{[18]}$ believes that before improving the quality evaluation index system of party building in colleges and universities, the scientific connotation of party building in colleges and universities should be clarified first. That is to understand the basic point and starting point of the party building work in colleges and universities. Secondly, the role of party building in colleges and universities should be understood. That is to understand the reasons why colleges and universities are tightly grasping party building work, and to understand the relationship between party building work and administrative work in colleges and universities. Finally, we must be clear about the actual benefits of party building in colleges and universities. That is, to understand the tangible effects of the promotion of party building work in colleges and universities on the overall healthy development of colleges and universities, and to see whether it takes into account the political and social nature of its nature, whether it takes into account the short-term and long-term, and whether it takes into account the method directly and indirectly. Wang Hongyan ${ }^{[19]}$ believes that in the setting of assessment indicators, it is necessary to fully reflect some key content, such as the strengthening of the political core role and the playing of the role of battle fortresses. 


\section{Theoretical and practical significance of the research on the quality evaluation system of party building work in colleges and universities in the new era}

\subsection{Theoretical significance}

\subsubsection{Supplement and perfection to the theory of party building in colleges and universities}

In today's theoretical framework of academic and practical research on party building work in colleges and universities, most of them focus on connotation analysis, significance, principle requirements, path innovation, etc. The main research areas are the content and content of party building work evaluation and evaluation. Too broad and macro, not in-depth and detailed. Then, the comprehensive and diversified research on the evaluation system of party building work quality in colleges and universities should be regarded as an important field and key content of theoretical research on party building in colleges and universities. This is also an objective need for the development of party building theory in colleges and universities to keep pace with the times and to innovate. Therefore, a detailed study of the "quality assessment" part of the party building work is a rich, perfect and powerful supplement to the party building theory.

\subsubsection{Strengthen the theoretical support for the practical work of party building}

Theory must be integrated with reality. Party building theory must ultimately be implemented in specific party building work. Assessment is an important part of party building work management. Without a scientific and reasonable assessment theory, it is impossible to construct a scientific, standard, and standardized quality assessment. The evaluation system, in turn, affects the overall quality and overall level of the party building work in colleges and universities, is related to the implementation of the purpose of establishing morality in colleges and universities, and is more related to the completion of the mission of running a socialist university with Chinese characteristics. Therefore, in-depth exploration and research on the quality evaluation system of party building work in colleges and universities is also hoping to provide strong theoretical support for the management and quality improvement of party building work in colleges and universities.

\subsection{Realistic significance}

\subsubsection{Responding to the realistic requirements of improving the quality of party building in the new era}

"Continuously improve the quality of party building, and build the party into a Marxist ruling party that is always in the forefront of the times, sincerely supported by the people, has the courage to revolutionize itself, can withstand the tests of various storms, and is vigorous and vigorous." [2] The general requirement to strengthen self-construction. "It is necessary to strengthen the party building work in various fields such as enterprises, rural areas, government agencies, institutions, and communities, and promote the overall progress of the grass-roots party organizations and their overall excellence" ${ }^{[20]}$. The purpose of studying the evaluation index system for party building in colleges and universities is to solve the management problems encountered in party building in colleges and universities, to improve the quality of party building in colleges and universities, to promote the progress and perfection of party organizations in colleges and universities, and to help the "full and strict governance of the party." The strategic deployment is firmly implemented in the grassroots party organizations in colleges and universities. Therefore, this is in response to the realistic requirements of improving the quality of party building in the new era.

4.2.2 The objective requirements for promoting the scientization, normalization and standardization of party building work in colleges and universities

Party building is of great significance and has a bearing on the overall development of the cause of socialism with Chinese characteristics. Party building work is highly political, involves a wide range of areas, and has a large workload. It includes not only party affairs, but also party political, ideological, organizational, work style, discipline, and system construction. It is a huge systematic project. As far as colleges and universities are concerned, if they want to run the huge project of party building work well and give play to its due political role, it must do everything possible to promote its own scientization, normalization and standardization construction. To achieve this goal, it is necessary to establish and improve an effective evaluation system. Through the assessment, work objectives and tasks can be further clarified, successful practical experience can be summarized in a timely manner, problems and deficiencies can be discovered and rectified in a timely manner. It can increase the importance of leading cadres and teachers and students at all levels of colleges and universities to the work of party building, mobilize the enthusiasm of all parties, and invest in the practice of party building in colleges and universities. Through the assessment, it is possible to test the scientificity and standardization of the party building work evaluation system in actual work, improve it in the test, and improve it in the promotion, thereby promoting the scientific, standardized and standardized level of party building work. 


\subsubsection{The inevitable requirement for colleges and universities to implement the purpose of establishing morality and fostering people and promote the construction of "Double First Class"}

"Universities are responsible for the important task of studying, researching and propagating Marxism and cultivating builders and successors of the cause of socialism with Chinese characteristics" [21]. "To run a socialist university with Chinese characteristics, we must adhere to the morality and cultivation of people, and the whole process of cultivating and practicing the core values of socialism, honoring teaching and educating people" [22]. The work of party building has always run through various tasks such as personnel training and scientific research in colleges and universities. The quality of party building work in colleges and universities affects the fulfillment of its purpose of morality and cultivation. The construction of party building assessment and evaluation index system is imperative. At the same time, the state's requirements for promoting the construction of "double first-class" and realizing the connotative development of higher education put forward higher requirements for party building. By strengthening the assessment of party building work, giving full play to the leadership core role of college party committees, comprehensively strengthening the construction of college leadership, cadres, faculty and student teams, and providing strong organizational guarantees and strong intellectual support for promoting the healthy and rapid development of colleges and universities. Establishing and perfecting the evaluation and evaluation system for party building work in colleges and universities is not only a practical need for the development of colleges and universities in the new era and for comprehensive and strict governance of the party, but also an inevitable requirement for promoting the construction of "double first-class".

\section{References}

[1] Xi Jinping. Leading the comprehensive and strict governance of the party to a deeper level with the perseverance on the road forever [J]. Party Building. 2018; (02): 8-9.

[2] Xi Jinping. Decisive victory to build a moderately prosperous society in an all-round way, and win the great victory of socialism with Chinese characteristics in the new era-a report at the 19th National Congress of the Communist Party of China [M]. Beijing: People's Publishing House; 2017.

[3] Xi Jinping. Implement comprehensive and strict governance of the party to every branch [J]. China Discipline Inspection and Supervision. 2016; (08): 2.

[4] Xi Jinping. Decisive victory to build a moderately prosperous society in an all-round way, and win the great victory of socialism with Chinese characteristics in the new era-a report at the 19th National Congress of the Communist Party of China [N]. People's Daily; 2017-10-28 (01).

[5] Xi Jinping. Speech at the National Organization Work Conference [J]. Contemporary Party Member. 2018; (19): 4-11.

[6] Xi Jinping. Putting ideological and political work through the whole process of education to create a new situation in the development of my country's higher education [N]. People's Daily; 2016-12-09 (01).

[7] Implementation Opinions on Upholding and Improving the Principal Accountability System under the Leadership of the Party Committee of Ordinary Colleges and Universities [N]. China Education News; 2014-10-16 (001).

[8] Li Yuanyuan, Zhang Qin. Research on Establishing and Improving the Evaluation System of Primary Party Organization Construction in Colleges and Universities [J]. High Education Journal. 2017; (10): 31-32.

[9] Du Hua. Discussion on the design of evaluation system for party building work in colleges and universities [J]. Ideological Education Research. 2017; (07): 93-96.

[10] Sui Jiatong, Feng Hongcai, Fu Yanzhi. Research on Party Building Issues and Countermeasures in Institutions of Higher Learning in the New Era [J]. Journal of Jinan Vocational College. 2020; (04): 68-70+87.

[11] Wang Deping. A Brief Discussion on the Assessment of the Party Branch of University Faculty and Staff [J]. Journal of Nanchang Hangkong University (Social Science Edition). 2020; 22(03): 39-42.

[12] Cao Qingkui, Tai Xiuzhen. Discussion on the appraisal system of grassroots party building work in colleges and universities [J]. Journal of Hebei University of Engineering (Social Science Edition). 2014; 31(04): 38-39+63.

[13] Luo Hongyan. Analysis on the evaluation index system of the party building work at the grassroots level in colleges and universities [J]. New West. 2017; (30): 127-129+138.

[14] Li Fangzheng. The construction and improvement of the evaluation system of the basic party building work in colleges and universities [J]. Century Bridge. 2018; (08): 48-4.

[15] Niu Heng, Gao Lina, Liu Shuang. The construction and thinking of the evaluation and assessment system of party building work at the grassroots level in colleges and universities [J]. Beijing Education (Moral Education). 2019; (01): 28-32.

[16] Fan Shan, She Tonghui, Tu Fang, Zhou Liyong, Xia Yang, Lin Ning. Construction of the Evaluation System for Party Building Work in Colleges and Universities [J]. Comparative Research on Cultural Innovation. 2017; 1(15): 20-22. 
[17] Niu Heng, Gao Lina, Liu Shuang. The construction and thinking of the evaluation system of the party building work at the grassroots level in colleges and universities [J]. Beijing Education (Moral Education). 2019; (01): 28-32.

[18] Fan Shan, She Tonghui, Tu Fang, Zhou Liyong, Xia Yang, Lin Ning. Construction of the Evaluation System of Party Building Work in Colleges and Universities [J]. Comparative Research on Cultural Innovation. 2017; 1(15): $20-22$.

[19] Wang Hongyan. Research on the Responsibility System and Evaluation System of the Party Building Work at the Grassroots Level in Colleges and Universities [J]. Education Teaching Forum. 2017; (29): 11-13.

[20] Effectively implement the party's organizational line in the new era, and the whole party strives to build the party stronger [N]. People's Daily; 2018-07-05 (01).

[21] Dong Hongliang. Xi Jinping made important instructions on the work of party building in colleges and universities, emphasizing adherence to the ideological guidance of morality and cultivating people, and strengthening and improving party building in colleges and universities [N]. People's Daily; 2014-12-30 (1).

[22] Xi Jinping gave important instructions on party building in colleges and universities. The portal website of the Ministry of Education of China. Available from: http://www.moe.edu.cn/publicfiles/business/htmlfiles/moe/s6629/201501/182856. html. 